\title{
Participative Management as a Critical Ingredient for TQM
}

\author{
*Sanjana Brijball Parumasur, Patsy Govender \\ University of KwaZulu-Natal (Westville Campus) Durban, South Africa \\ *brijballs@ukzn.ac.za
}

\begin{abstract}
Increasing competition has necessitated the need for human capital to ensure continuous improvement in quality in order to secure customer satisfaction, loyalty and sustainable development. This study aims to assess managerial perceptions of the extent and nature of participative management (delegation, involvement/empowerment, coaching, supportive leadership style) that takes place in the organization in efforts to achieve total quality management. Biographical influences on these managerial perceptions are also assessed. A sample of 202 managers (middle, senior, top) was drawn using a stratified random sampling technique. Data was collected using a pre-coded, self-developed questionnaire and analyzed using descriptive and inferential statistics. The findings reflect managers believe that participative management takes place at a moderate pace in the organization with the greatest focus being on coaching, followed by supportive leadership style, delegation and lastly, involvement/empowerment. Based on the results, recommendations for bringing about effective delegation, enhancing involvement/empowerment, ensuring valuable coaching and nurturing a supportive leadership style in efforts to accomplish TQM are presented.
\end{abstract}

Keywords: Participative management, delegation, involvement/empowerment, coaching, supportive leadership style, total quality management

\section{Introduction}

Total quality management (TQM), acclaimed as an organizational and a customer minded managerial philosophy (Thamizhmanii \& Hasan, 2010), involves continuous improvement, creativity, teamwork, delegation and participative management. TQM, traced over different times of evolution, has moved from a 'mechanistic approach' to a subjective organizational philosophy (Zakuan, Muniandy, Saman, Ariff, Sulaiman, \& Jalil, 2012). It has become an aspect of a corporate management parlance (Thamizhmanii \& Hasan, 2010) which helps to create participation, trust, teamwork, quality-mindedness, 'zeal for continuous improvement' and a culture to achieve ultimate success (Yusof \& Aspinwall, 2000 cited in Zakuan et al., 2000). Kreitner (2007) associates participative management with managerial attitude and power sharing and a set of practices that depend on trust. Participative management styles are in vogue globally, and it involves the demands of job meaningfulness, responsibility and collaboration (Stevens \& Ash, 2001 cited in Nadeem, 2012). Thus, both managers and employees need to be part of the improvement initiatives. Participative management, in a supportive climate, is to empower employees to take more control of the work environment (Kreitner, 2007), to foster more two-way interaction among team members and requires peoples' robust social skills (Lawler, 1992 cited in Nadeem, 2012). In this light, organizations require top management to promote employee participation (Zakuan et al., 2012), and by elevating continuous improvement via employee performance employees can contribute to TQM implementation on condition that command and control is reduced (Schminth \& Finnegan, 2003 cited in Zakuan et al., 2012). Furthermore, with a top-down approach through the various managerial levels (top, senior, middle) realistic goals and the flow of information cascades to all employees to participate in improvement initiatives.

There are differing views of quality gurus. Deming's participative management style, whose emphasis was on statistical techniques, differs from Juran's project by project implementation (Davies, 2001). A significant factor with an analysis of 41 participative studies indicated that a participative climate has a more positive effect on worker satisfaction than with participation in decision specific situations (Miller \& Monge, 1986 cited in Kreitner, 2007). Clearly, the momentum of participative management is step by step, involving trust and commitment. Participative decision-making equips managers and employees to explore all organizational activities, such as goal-setting, setting standards, and monitoring quality. Evidently, management theorists have found information to support the various managerial styles, for example, total quality management, participative management, management by walking around, and management by objectives. Participative management, a major aspect of TQM, boosts employee morale 
and this spells the required knowledge, skills, abilities, and other attributes (ksao) required to partake in engaging activities. Evidently, in New Zealand, 164 companies with about 100 employees found 'lower employee turnover' and 'higher organizational productivity' (Kreitner, 2007).

The four emergent factors of profit-sharing or gain-sharing plan, an employment relationship (longterm), building and maintaining cohesive groups and the protection of employee rights makes participation work (David, 1990 cited in Kreitner, 2007). Furthermore, quality control circles attempt to tap into employees' creative potential. Overall, it may not be evident but better worker-management relations, and enhanced individual commitment have been reported (Kreitner, 2007). Participative management encourages the involvement of all stakeholders organization-wide with problem analysis, developing strategies and implementing solutions (Nadeem, 2012). By providing the right leadership, employees develop their potential and hence, their participative management skills like communication, negotiation and compromise. This study assesses managerial perceptions of the extent and nature of participative management in an environment that has adopted the total quality management initiative. The study was undertaken in a municipality where participative management is imperative to ensure quality customer care and continuous improvement initiatives. It has the potential to provide insight into the employee trust and engagement, information flow, and employee performance. Specifically, it assesses the extent to which delegation, involvement/empowerment, coaching, and a supportive leadership style contributes to a customer and quality mindedness and continuous improvement environment.

Delegation: With a new tide in business, and job enrichment transforming peoples' work activities, managers assign work with decision-making authority, incorporating clarity and responsibility to employees. Delegating well-defined responsibilities is for quality achievement and is an integral aspect of getting things done. For the effective accomplishment of delegated tasks, employees need regular information from managers. By engaging followers in decision-making it enhances the desire to perform a work task (French, Rayner, Rees \& Rumbles, 2008). The multifaceted benefits of delegation includes the development of employees' skills and abilities as they need to focus on demanding tasks, stretching from their current level of functioning and hence, stimulating their creativity, potential and resulting in growth. This includes the optimization of employees' strengths. In a total quality environment, delegation is not abdication and managers who focus on demanding and strategic issues have the last say. Effective delegation necessitates that a manager shares a sense of direction by:-

- Clarifying the importance of the task and what is required of the subordinate.

- Stringently allocating the task to the most suitable employee for facilitation of task accomplishment and employee development and ensuring that the person is authorised to undertake the task.

- Clearly communicating information such as, the nature and purpose of the task, the expected outcomes, priority of the task, deadlines and the monitoring process.

- Ensuring that the employee has the resources and time that the task demands.

- Ensuring that communication channels are open for consultation, feedback, input and discussion.

- Allowing flexibility and displaying trust in the employee's abilities (Quinn, Faerman, Thompson \& McGrath, 2003). Hence, the employee is given the opportunity to assess the progress of the task, take corrective action and engage in decision-making and problem-solving thereby extending his/her skills and abilities.

- Recognising the employees' efforts and showing appreciation by acknowledging employee accomplishments.

Delegation contributes to organizational success, increases effectiveness, and improves decision-making in terms of quality initiatives. Subordinates should be qualified (right skills) to receive, and keen to accept, the task. Through effective delegation, managerial tasks can be prioritized. Both, the organization and the subordinate can be 'beneficiaries of delegation' in a TQM environment. Managers need to delegate sufficient authority for the accomplishment of TQM for collective decision-making. The failure of TQM is due to top management's reluctance in delegating authority to employees (Minjoon, Shaohan \& Hojung, 2006).

Involvement/Empowerment: For the effective implementation of TQM processes and practices, managers must involve, enable and empower their workers (Wicks, 2001) to formulate action plans that shape the business vision, mission and their commitment to organizational goals (Oakland \& Oakland, 2001). Empowerment connects peoples' strengths and competencies, and assists systems and proactive 
behaviour to align with social policy and social change (Thamizhmanii \& Hasan, 2010). It is operationalized when they are encouraged to respond to quality problems and provided them with resources and authority (Ugboro \& Obeng, 2000). Empowerment entails sharing organizational factors regarding organizational performance, rewards which are based on organizational performance, knowledge to enable employees to understand and make contributions to organizational performance and decision-making power to influence an organization's future direction and performance (Bowen \& Lawler, 1992 cited in Quinn et al., 2003). This reciprocal relationship includes a shift of power from higher levels of the hierarchy to employees at the lower level, which outlines the delegation of responsibility, decision-making, problem-solving and power sharing to employees. Employees feel a sense of empowerment and the more they perceive their efforts to be flourishing, the more they feel empowered (Daily \& Bishop, 2003). Some advantages in a quality management perspective include:-

- It enhances employee commitment to organizational success (Evans, 2005).

- It improves productivity, organizational quality, organizational performance and employee attitudes which are essential to secure a significant market share (Lawler, 1994; Daily \& Bishop, 2003).

- Empowerment enables employees to foresee organizational changes.

- The sharing of decision-making authority will motivate employees to exert optimum effort and take calculated risks (Gitlow, Oppenheim, Oppenheim \& Levine, 2005).

- Empowered employees are more likely to take ownership for solving problems or responding to marketplace opportunities, in facilitating improvement, making effective decisions (Evans \& Lindsay, 2005), building relationships, working in effective teams and engaging in quality improvement activities designed by management (Korukonda, Watson \& Rajkumar, 1999).

- Involvement leads to self-motivation and empowerment and facilitates self-control and problemsolving skills (Korukonda et al., 1999).

- Employee morale and confidence is boosted due to a sense of satisfaction, accomplishment and flexibility.

- Empowerment enables self-managed work teams to effectively manage problems relating to productivity and quality, including team support. With ownership, responsibility and empowerment, employees can make changes to ensure the ultimate success of a quality end result.

Empowered employees have responsibility, a sense of ownership, and recognition (Turney, 1993), to seek improvements and align with the managerial philosophy of satisfying customers (Thamizhmanii \& Hasan, 2010). For success, a TQM program must be complemented by a genuine employee involvement effort (Daily \& Bishop, 2003). TQM and employee involvement and empowerment are compatible and have proven to lead to higher levels of productivity gains and employee satisfaction (Wicks, 2001). TQM managers are expected to get employee trust, encourage problem-solving and promote departmental cooperation (Thamizhmanii \& Hasan, 2010). A criterion of the European Foundation of Quality Management (EFQM) emphasizes employee contribution through their development and involvement (Michalska, 2008 cited in Thamizhmanii \& Hasan, 2010). Employees own and improve quality processes, whereas teams need to identify the best course of action in every context, within boundaries (Thamizhmanii \& Hasan, 2010).

Coaching: Coaching, a developmental intervention is evident in numerous areas, such as staff motivation, team building and quality improvement initiatives. Often, coaching entails ongoing meetings with managers and employees addressing career and development. It unlocks people's potential via awareness and builds a 'can-do' attitude (Taie, 2011). As a partnership process, coaching inspires and energizes an employee's performance, and needs to be introduced to bring about organizational change to reduce the gap between learning and practice (Taie, 2011). Crabb (2011) tends to mirror this line of thought by indicating that organizations are starting to adopt the practice of coaching which enhances employee skill development and well-being in order to achieve performance.

With more workers, managers are faced with a time factor with employee development. Coaching and counselling are important in recognising and rewarding improved and positive performance and for correcting problem behaviours or attitudes (Whetton \& Cameron, 2005). Development is evident when coaching takes place with highly skilled employees (Noe, 2008). The focus is idea sharing, goals, 'one-onone' with an employee, providing feedback, a 360-degree assessment, and putting workers into contact with experts. Open-mindedness is imperative, as coaches need to suggest effective improvement actions and respect employee confidentiality. Wachovia Corporation, a financial company uses an executive 
coaching programme which utilizes internal and external coaches. Participants in this programme receive 360-degree assessment which they take to their internal coaches from a different unit within the organization (Noe, 2008). After review they agree on an action plan. The coaches are trained with the positive and negative side of 360-degree feedback. Considering this, in an environment focusing on product and service quality improvement, developmental coaching is definitely imperative to lay a firm foundation to reach ultimate goals.

Team members too require special coaching and counselling (Dale, van der Wiele \& van Iwaarden, 2007). Coaching must be part of leadership development initiatives as strategic coaching goals are for organizational outcomes. Coaching improves performance; therefore, organizations need to develop leaders who are capable coaches. Via coaching dialogues, Crabb (2011) proposes that people can work to use their strengths, align their values to the organization effectively, serving to enhance well-being and to achieve optimal performance. Leonard-Cross (2010) is of the view that the pursuance of a coaching culture is beneficial and with the 'generic nature' of many coaching skills, leaders can improve their managerial skills (Wilson, 2005 cited in Leonard-Cross, 2010). Coaching is a reiterative process in organizations that are striving to achieve productivity, quality and continuous engagement, hence requiring managers to engage in contingency thinking as the future workforce will become the corporate norm.

Supportive Leadership Style: For a holistic approach to an organization's TQM programme, managers need to develop, empower and support employees in ensuring quality products and services, meeting customer needs and satisfaction, analysing and improving processes in functional areas to reach optimum levels of productivity in accomplishing organizational goals. Leadership is a core principle of quality improvement initiatives and striving for quality management requires positive change. With transformational leadership, followers are empowered, they become 'partners' in the change process and their interests are broadened and elevated (French et al., 2008). Leaders are encouraged to look past their own self-interest by considering others and their confidence enables them to exceed expectations.

A supportive leadership style as an integral aspect of the management philosophy fits into the core of the organizational strategy and quality initiatives. A key aspect of the Malcolm Baldridge National Quality Award (MBNQA) is leadership, and it highlights its importance in quality performance, and promotes visionary leadership (Alharbi \& Yusoff, 2012). TQM advocates specify that customer satisfaction is evident with management commitment, whereby the organizational environment empowers employees with the core focus being customer satisfaction (Ugboro \& Obeng, 2000). Participative management creates a balance with manager and subordinate involvement relating to information processing, decision-making and problem-solving, amongst others (Wagener, 1994 cited in Nadeem, 2012). Quality advocates emphasize that feedback must follow performance evaluations for improvements to take place. Considering this, subjective feedback from managers, peers and customers and objective feedback based on processes using control methods are essential (Noe, Hollenbeck, Gerhart \& Wright, 2008). Effective managers perform the basic functions of planning and organizing and they develop and work collaboratively with employees (Noe, 2008).

Noted as a unitarist management style, a TQM tenet is that managers and employees share the same objectives (Fox, 1974 cited in Dale et al., 2007). To sustain TQM, a shift from a radical (opposing interest) or pluralist management style (recognizing peoples' rights) to a unitarist position (having common goals) is necessary (Dale et al., 2007). New boundaries of quality management practices could be impacted by transformational leadership with leaders taking the role of motivating, involving and engaging subordinates to do their best (Alharbi \& Yusoff, 2012). Management support is important for quality management in providing direction for workers' satisfaction (Ng, Goh \& Eza, 2010 cited in Alharbi \& Yusoff, 2012). The commitment of top managers is needed to enhance quality, and participative management is at the core of all TQM initiatives as it is always leader-driven.

Aims of the study: This study aims to assess managerial perceptions of the extent and nature of participative management (delegation, involvement/empowerment, coaching, supportive leadership style) in a total quality management initiative. Biographical influences on these managerial perceptions are also assessed. 


\section{Methodology}

Research approach: The research methodology has been designed to assess the importance of participative management in a total quality management (TQM) initiative using a survey approach.

Respondents: The population comprised of middle, senior and top management in a large public sector department in eThekweni (Durban) in South Africa. The population comprised of approximately 400 managers. The sample of 202 subjects was drawn using a stratified random sampling technique to ensure proportionate representation from the strata of the designated groups of interest, that is, managers. According to the population-to-sample size table by Sekaran (2003), the corresponding minimum sample size for a population of 400 is 196 , thereby confirming the adequacy of the sample size for this study. In terms of the composition, $12.9 \%$ of the sample consisted of top managers, $32.7 \%$ were senior managers and $54.4 \%$ were middle managers. In addition, $29.7 \%$ of the respondents were 50 years and older, $39.1 \%$ were between $40-49$ years, and $24.8 \%$ were between $30-39$ years with only $6.4 \%$ being below 30 years. White respondents made up $34.7 \%$ of the respondents, followed by Indians (39.1\%), Blacks $(19.8 \%)$ and Coloureds (6.4\%). In terms of tenure, $24.8 \%$ of the respondents worked in the organization for 21 years and over, $16.8 \%$ served for $16-20$ years, $27.2 \%$ for $11-15$ years, $21.3 \%$ served for a term of $6-10$ years and only $9.9 \%$ were between $0-5$ years in the company. The majority of the subjects have a postgraduate degree $(40.6 \%)$, followed by those who hold a first degree $(24.3 \%)$, those who have a diploma certificate (16.3\%), a postgraduate diploma certificate (10.4\%) and 8.4\% who have between Standard 8-10 (Grade $10-12)$. The majority of the subjects were males $(85.1 \%)$ with only $14.9 \%$ being females, thereby indicating the disproportionate percentage of females to males in management. The adequacy of the sample was further determined using the Kaiser-Meyer-Olkin Measure of Sampling Adequacy (0.858) and the Bartlett's Test of Spherecity (1874.631, $\mathrm{p}=0.000$ ) for the sub-dimensions of participative management (delegation, involvement/empowerment, coaching, supportive leadership style) which respectively indicated suitability and significance. The results indicate that the normality and homoscedasticity preconditions are satisfied.

Measuring Instrument: Data was collected using a self-developed questionnaire consisting of Section A (biographical information) and Section $B$ which included items relating to the sub-dimensions of participative management. The biographical data in Section A was collected using a nominal scale with pre-coded option categories and the items in Sections B were measured using a 5-point Likert scale ranging from strongly disagree (1), disagree (2), neither agree/not disagree (3), agree (4) to strongly agree (5). The questionnaire was formulated on the basis of identifying recurring themes that surfaced during the literature review and the 23 items included in the questionnaire related directly to the constructs being measured $(10$ items related to delegation, 8 items pertained to involvement/empowerment, 2 items related to coaching and 3 items pertained to supportive leadership style). This ensured face, content and construct validity. Furthermore, in-house pretesting was adopted to assess the suitability of the instrument. Pilot testing was also carried out using 12 subjects, selected using the same procedures and protocols adopted for the larger sample. The feedback from the pilot testing confirmed that the questionnaire was appropriate in terms of relevance and construction.

Statistical measures of the questionnaire: The validity of the questionnaire was assessed using Factor Analysis. A principal component analysis was used to extract initial factors and an iterated principal factor analysis was performed using SPSS with an Orthogonal Varimax Rotation. Only items with loadings $>0.4$ were considered to be significant and when items were significantly loaded on more than one factor only that with the highest value was selected. In terms of the sub-dimensions of participative management (Section B), four factors with latent roots greater than unity were extracted from the factor loading matrix. Factor 1 relates to supportive leadership style and accounts for $17.39 \%$ of the total variance, Factor 2 relates to involvement/empowerment and accounts for $15.31 \%$ of the total variance, Factor 3 relates to delegation and accounts for $12.72 \%$ of the total variance and Factor 4 relates to coaching and accounts for $7.70 \%$ of the total variance in determining participative management as a strategy for achieving total quality management. The reliability of Section B of the questionnaire relating to the sub-dimensions of participative management was determined using Cronbach's Coefficient Alpha (Alpha $=0.898$ ). This alpha coefficient indicates a very high level of internal consistency of the items and hence, a high degree of reliability. The reliabilities for the individual sub-dimensions of participative management were also assessed. Whilst delegation (alpha $=0.788$ ), involvement/empowerment (alpha $=$ 0.840 ) and supportive leadership style (alpha $=0.758$ ) reflected strong reliabilities, the inter-item consistency for coaching (alpha $=0.583$ ) displayed a moderate level of reliability. 
Administration of the measuring instrument: The questionnaires were administered over a three month period and respondents could either post the questionnaire in the attached self-addressed envelope or send them electronically to the researchers.

Statistical analysis: Descriptive (means, standard deviations) and inferential (correlation, ANOVA, t-test, Post Hoc Scheffe's test) statistics were used to analyze the quantitative data. The data was captured using Excel (Version 5), processed with Simstat and presented using tabular and graphical representations.

\section{Results}

Managerial perceptions of efforts to ensure participative management in order to enhance total quality management were determined by of assessing the extent to which the organization engages in delegation, involvement/empowerment, coaching and supportive leadership style (Table 1).

Table 1: Descriptive Statistics - Participative management

\begin{tabular}{|c|c|c|c|c|c|}
\hline \multirow[b]{2}{*}{ Statistic } & \multicolumn{5}{|c|}{ Participative management } \\
\hline & Overall & Delegation & $\begin{array}{l}\text { Involvement/ } \\
\text { empowerment }\end{array}$ & Coaching & $\begin{array}{l}\text { Supportive } \\
\text { leadership style }\end{array}$ \\
\hline Mean & 3.1634 & 3.1657 & 3.0491 & 3.3433 & 3.2720 \\
\hline 95\% Confidence Lower Bound & 3.0701 & 3.0706 & 2.9304 & 3.2227 & 3.1436 \\
\hline Interval for Mean Upper Bound & 3.2567 & 3.2608 & 3.1679 & 3.4639 & 3.4004 \\
\hline Variance & 0.434 & 0.467 & 0.729 & 0.752 & 0.852 \\
\hline Std. Deviation & 0.6590 & 0.68371 & 0.85367 & 0.86693 & 0.92322 \\
\hline Minimum & 1.09 & 1.30 & 0.38 & 0.00 & 0.00 \\
\hline Maximum & 5.00 & 5.00 & 5.00 & 5.00 & 5.00 \\
\hline
\end{tabular}

Overall, managerial perceptions of participative management in efforts to achieve total quality management is fairly positive (Mean $=3.1634$ ). In this organization, the focus is on coaching (Mean = 3.3433 ), followed by adopting a supporting leadership style (Mean $=3.2720$ ), delegation $($ Mean $=3.1657$ ) and lastly, involvement/empowerment (3.0491). Against a maximum attainable score of 5, there is room for improvement in each of the sub-dimensions of participative management, particularly with regards to involvement/empowerment. Frequency analyses were computed to obtain greater insight into these managerial perceptions. With regards to coaching, just over half of the managers agreed or strongly agreed that coaching in the organization equips employees to manage customer complaints effectively (59\%) or that coaching and counselling prepares them by developing skills to improve standards of performance (58\%). With regards to adopting a supportive leadership style, $68.8 \%$ of the managers believed that effective team leaders in the organization contributes to achieving optimum levels of productivity. However, managers were not convinced that employee development $(53.9 \%)$ and empowerment of employees by leaders (49.5\%) contributes to achieving optimum levels of productivity.

With regards to delegation, $65.4 \%$ of the managers believed that when work is delegated there is clear communication with information such as expected outcomes and deadlines and $63.4 \%$ agreed or strongly agreed that effective delegation in the organization leads to task clarification. However, more than half of the managers did not agree that with delegation, employees are provided with adequate resources $(61.4 \%)$ and have sufficient time that the task demands (57.9\%). Furthermore, managers are not convinced that with delegation there is job flexibility (55.9\%) and that every attempt is made to recognize and appreciate employees' efforts (51.6\%). With regards to involvement/empowerment, managers agreed or strongly agreed that with involvement/empowerment in the organization employees' efforts are aimed at organizational success $(61.9 \%)$ and that an environment of trust is created $(58.9 \%)$. However, more than half of the managers were not convinced that with involvement/empowerment, employees' rewards are based on the organizations' performance (67.4\%), that employees have a certain amount of latitude that they can take (67.3), that employees are empowered to make decisions that contribute to organizational direction and performance (56.4\%), and that employees have adequate knowledge which equips them to understand and contribute to organizational performance $(55.9 \%)$. Furthermore, $48.4 \%$ of the managers did not believe that with involvement/empowerment employees experience a 'hands-off' leadership approach. 
Hypothesis 1: There sub-dimensions of participative management that have the potential to contribute to total quality management (delegation, involvement/empowerment, coaching, supportive leadership style) significantly correlate with each other (Table 2).

Table 2: Intercorrelation - Sub-dimensions of Participative Management

\begin{tabular}{lllll}
\hline Sub-dimension & Delegation & $\begin{array}{l}\text { Involvement/ } \\
\text { empowerment }\end{array}$ & Coaching & $\begin{array}{l}\text { Supportive } \\
\text { leadership style }\end{array}$ \\
\hline $\begin{array}{l}\text { Delegation } \\
\text { Involvement/empowerment }\end{array}$ & 0.663 & 1 & & \\
& $0.000^{*}$ & & & \\
Coaching & 0.372 & 0.332 & 1 & \\
& $0.000^{*}$ & $0.000^{*}$ & & \\
Supportive leadership style & 0.482 & 0.582 & 0.473 & 1 \\
& $0.000^{*}$ & $0.000^{*}$ & $0.000^{*}$ & \\
\hline
\end{tabular}

$* \mathrm{p}<0.01$

Table 2 indicates that the sub-dimensions of participative management that have the potential to contribute to total quality management (delegation, involvement/empowerment, coaching, supportive leadership style) significantly correlate with each other at the $1 \%$ level of significance. Hence, hypothesis 1 may be accepted. The implication is that an improvement or change in any one of these sub-dimensions has the potential to impact on the other sub-dimensions thereby, influencing total quality management. The combined improvement of all the sub-dimensions will have a snowballing effect and exponentially contribute to participative management and hence, the realization of TQM. Table 2 also reflects a fairly strong relationship between delegation and involvement/empowerment $(r=0.663)$.

Hypothesis 2: There is a significant difference in the perceptions of managers varying in biographical data (position, age, race, tenure, academic qualification, gender) regarding each of the sub-dimensions of participative management that have the potential to contribute to total quality management (Tables 3-6).

Table 3: ANOVA and t-test - Biographical Variables and Sub-dimensions of Participative management

\begin{tabular}{|c|c|c|c|c|c|c|c|c|c|c|c|c|c|}
\hline \multirow{3}{*}{$\begin{array}{l}\text { Participative } \\
\text { management } \\
\text { and sub- } \\
\text { dimensions }\end{array}$} & \multicolumn{8}{|c|}{ ANOVA } & \multicolumn{5}{|c|}{ t-test } \\
\hline & \multicolumn{2}{|c|}{$\begin{array}{l}\text { Current } \\
\text { Position }\end{array}$} & \multicolumn{2}{|l|}{ Age } & \multicolumn{2}{|l|}{ Race } & \multicolumn{2}{|c|}{ Tenure } & \multicolumn{2}{|c|}{$\begin{array}{l}\text { Academic } \\
\text { Qualification } \\
\text { s }\end{array}$} & \multicolumn{2}{|c|}{ Gender } & \\
\hline & $\mathrm{F}$ & $\mathrm{P}$ & $\mathrm{F}$ & $\mathrm{p}$ & $\mathrm{F}$ & $\mathrm{p}$ & F & $\mathrm{p}$ & F & $\mathrm{P}$ & $\mathrm{t}$ & df & $\mathrm{p}$ \\
\hline $\begin{array}{l}\text { Participative } \\
\text { management }\end{array}$ & 1.09 & 0.338 & 0.493 & 0.687 & 0.48 & 0.69 & 1.16 & 0.958 & 1.78 & 0.14 & 0.22 & 196 & 0.81 \\
\hline Delegation & 2.35 & 0.098 & 0.27 & 0.846 & 0.24 & 0.87 & 0.23 & 0.924 & 2.02 & 0.09 & -1.04 & 195 & 0.30 \\
\hline $\begin{array}{l}\text { Involvement/em } \\
\text { powerment }\end{array}$ & 0.442 & 0.656 & 0.610 & 0.609 & 0.68 & 0.56 & 0.67 & 0.615 & 1.27 & 0.28 & 0.28 & 196 & 0.78 \\
\hline Coaching & 6.122 & $0.003^{*}$ & 2.885 & $0.037^{* *}$ & 0.45 & 0.72 & 4.94 & $0.001^{*}$ & 1.73 & 0.15 & 0.18 & 196 & 0.86 \\
\hline $\begin{array}{l}\text { Supportive } \\
\text { leadership style }\end{array}$ & 0.241 & 0.786 & 0.871 & 0.457 & 0.82 & 0.48 & 0.25 & 0.912 & 0.49 & 0.75 & -0.22 & 196 & 0.83 \\
\hline
\end{tabular}

Table 3 indicates that the perceptions of managers varying in current position (top, senior, middle managers) and tenure regarding coaching, differs significantly at the $1 \%$ level of significance. Furthermore, managers varying in age differ significantly in their views of coaching in the organization, at the $5 \%$ level of significance. No other significant biographical influences were noted in Table 3 . Hence, hypothesis 2 may only be partially accepted in terms of managerial views of coaching. In order to assess exactly where these significant differences lie, the Post Hoc Scheffe's test was computed (Tables $4-5$ ). 
Table 4: Post Hoc Scheffe's Test - Current Position and Coaching (Multiple Comparisons)

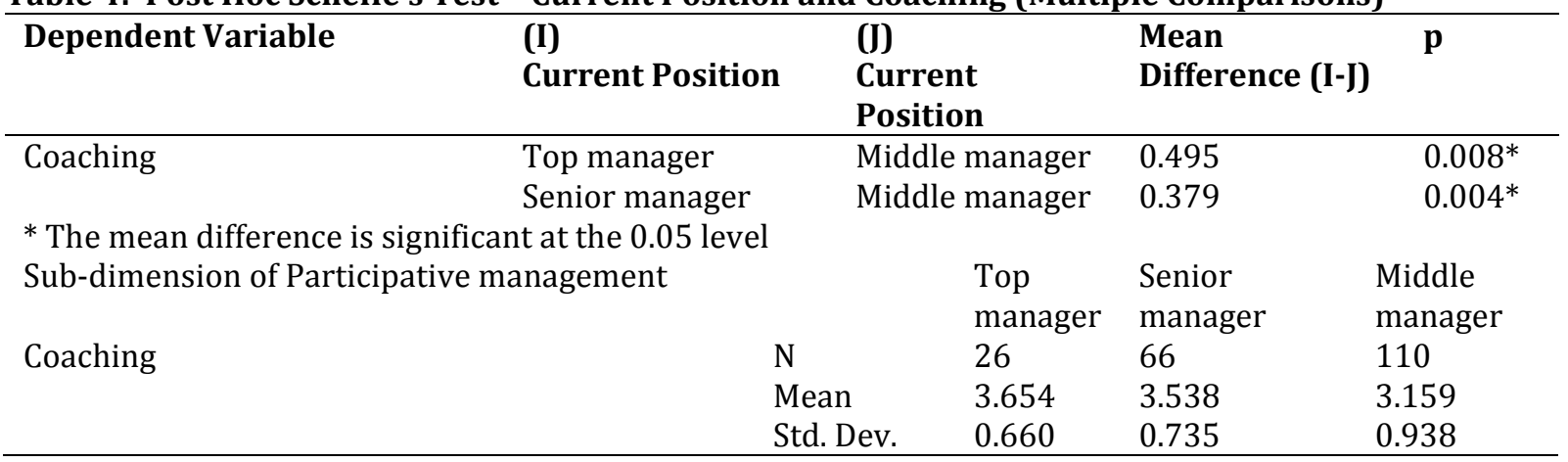

The mean differences in the Post Hoc Scheffe's Test results (Table 4) indicate that top managers (Mean = 3.654 ) and senior managers $($ Mean $=3.538$ ) differ significantly from middle managers (Mean $=3.159$ ) with regards to coaching. Evidently, middle managers are not as convinced as their counterparts (top and senior managers) that coaching as a part of participative management is effectively undertaken to bring about total quality management in the organization.

Table 5: Post Hoc Scheffe's Test - Tenure and Coaching (Multiple Comparisons)

\begin{tabular}{|c|c|c|c|c|}
\hline $\begin{array}{l}\text { Dependent } \\
\text { Variable }\end{array}$ & (I) Tenure & (J) Tenure & Mean Difference (I-J) & $\mathbf{p}$ \\
\hline \multirow{4}{*}{ Coaching } & $0-5$ years & $11-15$ years & 0.779 & $0.002^{*}$ \\
\hline & $16-20$ years & $11-15$ years & 0.388 & $0.036^{*}$ \\
\hline & 21 years and over & $06-10$ years & 0.347 & $0.050 *$ \\
\hline & & $11-15$ years & 0.659 & $0.000 *$ \\
\hline \multicolumn{5}{|c|}{ * The mean difference is significant at the 0.05 level } \\
\hline $\begin{array}{l}\text { Sub-dimensi } \\
\text { Management }\end{array}$ & $n$ of Participative & Years & Mean & Std. Deviation \\
\hline \multirow{5}{*}{ Coaching } & $\mathrm{N}=13$ & $0-5$ years & 3.808 & 0.751 \\
\hline & $\mathrm{N}=43$ & $6-10$ years & 3.314 & 0.946 \\
\hline & $N=55$ & $11-15$ years & 3.009 & 0.940 \\
\hline & $N=34$ & $16-20$ years & 3.397 & 0.796 \\
\hline & $\mathrm{N}=50$ & 21 years and over & 3.660 & 0.666 \\
\hline
\end{tabular}

The mean differences in the Post Hoc Scheffe's Test results (Table 5) indicate that with regards to coaching, managers who are $0-5$ years in the company (Mean $=3.808$ ) differ significantly from managers with a tenure of 11-15 years (Mean $=3.009)$. This indicates that with regards to coaching, managers with tenure of 0-5 years have a more positive perception of coaching as a participative management technique aimed at bringing about total quality management than those who are 11-15 years in the organization. Furthermore, there is a significant difference between managers with a tenure of 16-20 years (Mean = 3.397) and those with 11-15 years, whereby the former have a more positive perception of coaching as it takes place in the organization than the latter. Lastly, managers with a tenure of 21 years and over (Mean $=3.660$ ) differ significantly from those who are 6-10 years in the organization, with the former having a more positive view of coaching than the latter. Clearly, managers with a tenure of $0-5$ years are most optimistic of the manner in which coaching is taking place in the organization than those with a longer tenure.

The mean differences in the Post Hoc Scheffe's test results (Table 6) indicate that with regards to coaching, managers who are 40-49 years of age (Mean $=3.487$ ) and those who are 50 years and over $($ Mean $=3.433)$ differ significantly from those who are 30-39 years of age (Mean $=3.070)$. Hence, the implication is that managers who are 40 years and over are more convinced that coaching is effectively taking place in the organization than those who are younger (especially those who are 30-39 years old). 
Table 6: Post Hoc Scheffe's Test - Age and Coaching (Multiple Comparisons)

\begin{tabular}{|c|c|c|c|c|c|}
\hline Dependent Variable & \multicolumn{2}{|l|}{ (I) Age } & (J) Age & \multicolumn{2}{|c|}{$\begin{array}{l}\text { Mean } \\
\text { Difference (I-J) }\end{array}$} \\
\hline \multirow[t]{2}{*}{ Coaching } & \multicolumn{2}{|c|}{ 40-49 years } & 30-39 years & 0.417 & $0.008^{*}$ \\
\hline & \multicolumn{2}{|c|}{50 years and over } & 30-39 years & 0.363 & $0.028^{*}$ \\
\hline \multicolumn{6}{|c|}{ * The mean difference is significant at the 0.05 level } \\
\hline \multirow{2}{*}{$\begin{array}{l}\text { Sub-dimension } \\
\text { Participative management } \\
\text { Coaching }\end{array}$} & & $20-29$ years & $30-39$ years & $40-49$ years & $\begin{array}{l}50 \text { years } \\
\text { and over }\end{array}$ \\
\hline & $\mathrm{N}$ & 11 & 50 & 79 & 60 \\
\hline & Mean & 3.136 & 3.070 & 3.487 & 3.433 \\
\hline & Std. Dev. & 0.505 & 1.036 & 0.851 & 0.733 \\
\hline
\end{tabular}

Discussion of Results: The results (Mean $=3.1634)$ indicate that participative management takes place at a moderate pace in the organization with the greatest focus being on coaching (Mean $=3.3433$ ), followed by supportive leadership style $($ Mean $=3.2720)$, delegation $($ Mean $=3.1657)$ and lastly, on involvement/empowerment (Mean $=3.0491$ ). Evidently, against a maximum attainable score of 5 , there is room for improvement in participative management in efforts to achieve total quality management with the greatest improvement needed in the involvement/empowerment of employees. Research findings indicate that an organization may attain a more successful quality system if it implements a TQM program that is complemented by a genuine employee involvement effort (Daily \& Bishop, 2003). TQM can be a powerful approach for unleashing employee creativity and potential, reducing bureaucracy and costs, and enhancing customer service (Jha \& Kumar, 2012). However, employee empowerment can only be completely successful if the following founding ingredients exist in the organization: an environment of trust, genuine worker efforts directed at organizational success, managers being trained to adopt a 'hands-off' leadership approach and employees being trained for the amount of latitude that they can take (Evans \& Lindsay, 2005).

The results also reflect that the sub-dimensions of participative management (delegation, involvement/empowerment, coaching, supportive leadership style) significantly relate to each other at the $1 \%$ level of significance. In particular, delegation significantly relates to coaching at the $1 \%$ level of significance. Supporting this view, Vinton (1987) asserts that delegation can be a tool in the development of employees' skills, knowledge, and self confidence. The author, however, cautions that the delegation process is viewed as being 'subtractive', meaning that what is delegated is removed from the manager instead of bringing managers and employees consulting together to define, for example, tasks and meeting organizational goals (Vinton, 1987). Furthermore, this view excludes the central role of managers as coaches in providing training, support and guidance throughout the task in order to effectively delegate (Vinton, 1987). However, in the current study, it was found that there is a significant and fairly strong relationship between involvement/empowerment and coaching at the $1 \%$ level of significance. This outcome is supported by Vora's (2004) view that in order to manage knowledge workers, it is important to empower people and provide general direction. Furthermore, the benefits of employee empowerment are the facilitation of self-control, critical thinking and problem solving skills (Gabor, 1990 cited in Korukonda et al., 1999). The findings also reflect that delegation significantly relates to involvement/empowerment at the $1 \%$ level of significance. Scully (1993) cautions that some people view empowerment as more delegation in the guise of indirect control.

Korukonda et al. (1999) adds that in numerous real-life cases, empowerment accounted to no more than the delegation of additional duties to employees. The results of the current study also reflect that delegation significantly relates to a supportive leadership style. Joiner (2006) found that if employees do not receive acknowledgement and support from the leadership or from work colleagues, the implementation of TQM programmes may be not be fully realized. Similarly, research findings indicate that a guide for effective delegation is to give employees freedom to undertake tasks 'in their own way' while 'establishing agreed-upon results' and performance standards (Vinton, 1987). Joiner (2006) emphasizes that organization support that nurtures a positive two-way relationship between employees and leadership and a strong collegial support that promotes knowledge sharing enables a synergistic effect on the TQM/performance relationship. However, Miller and Cangemi (1993) believe that managers 'cannot delegate quality' as they fail to comprehend that quality must be embedded in everyone who gets paid from the company and many managers fail to see quality as a foundational tool for their organization's strategic planning (Miller \& Cangemi, 1993). Furthermore, the results of the current study indicate that involvement/empowerment significantly relates to a supportive leadership style. This result 
is supported by a similar view that transformational leadership, amongst others, nurtures worker empowerment by maintaining high expectations (House, 1995 cited in Wicks, 2001). This leadership style can facilitate the empowerment process (House, 1995 cited in Wicks, 2001). However, Tushman and Anderson (2004) cautions that a potential disadvantage observed with regard to empowerment is that employees construe it as a psychological contract with the organization yet the boundaries of their responsibility and freedom are not always clarified. Furthermore, the findings reflect a significant relationship between a supportive leadership style and coaching at the $1 \%$ level of significance. Research emphasizes that there is no one best way to manage employees; instead, managers aiming to effectively lead people to higher levels of performance need to adapt their style to align with the development level of the people they are managing, for example, high directive/high supportive behaviour is equivalent to coaching (Ignite, 2007).

The significant inter-correlation of the sub-dimensions of participative management (delegation, involvement/empowerment, coaching, supportive leadership style) emphasize that an improvement in any one sub-dimension of participative management has the potential to have a snowballing effect and enhance all the other sub-dimensions as well as total quality management. A combined improvement in all the sub-dimensions of participative management, therefore, has the potential to enhance total quality management exponentially. These results also emphasize the importance of the holistic involvement of human capital, and of integrating human resource management, into the TQM process.

Impact of biographical data on participative management: With regards to the influence of biographical data, it was found that there is a significant difference amongst employees varying in current position, tenure and age regarding coaching. In terms of current position, tenure and age it was respectively found that the higher the managerial level, the greater the tenure and the older the manager, the stronger the perception that coaching is taking place in the organization. Hence, it is important to inform lower levels of management, younger managers and those with lesser tenure of all coaching techniques adopted in the organization as they regularly coach employees and adopt standards to assist them in correcting their behaviours and improving their skills to enhance employee development, accomplish work tasks, ensure quality and improved performance. No significance difference was found amongst employees varying in the other biographical data (race, academic qualifications, gender) regarding participative management and its sub-dimensions. However, with regards to participative management and race, Quang and Vuong (2002) noted that management styles are influenced by the social cultures in which companies function. For example, Japanese have a different management style compared to Indians, the Americans or the British (Quang \& Vuong, 2002). Also, contrary to the findings of this study, with regards to participative management and academic qualifications, Brown (1999) asserts that client-based qualifications as opposed to non-accredited in-house management development programmes could create higher participant energy levels.

\section{Recommendations and Conclusion}

With regards to participative management, it is recommended that:

- When delegating, ensure that employees have sufficient time that the task demands and, thereafter ensure that employees perceive the occurrence of job flexibility.

- With involvement/empowerment, institute employee rewards based on the organization's performance and ensure that employees have a certain amount of latitude that they can take.

- Coach and counsel employees to prepare them with the standards of performance required for improving skills and coach employees to manage customer complaints effectively.

- Use a supportive leadership style, and ensure that employee development and empowerment of employees takes place in the organization to achieve optimum levels of productivity. An environment of support provides a synergistic boost to organizational performance (Joiner, 2006).

Effective delegation necessitates that the manager:

- Clarifies the task's importance and what is required of the subordinate.

- Stringently allocates the task to the most suitable employee authorised to undertake the task to facilitate task accomplishment.

- Communicates important information regarding the nature, purpose and priority of the task, the expected outcomes and deadlines.

- Ensures the existence of communication channels. 
- Allows flexibility and displays trust in the employee's abilities creating an opportunity to extend his/her skills and abilities.

- Monitors the progress of the task.

- Recognizes and shows appreciation by acknowledging employee accomplishments.

The organizational ingredients critical for involvement/empowerment include:

- An environment of trust.

- Genuine worker efforts directed at organizational success.

- Managers being trained to adopt a 'hands-off' leadership approach,

- Employees being trained for the amount of latitude that they can take (Evans \& Lindsay, 2005).

Positive reflections with employee involvement/empowerment:

- Improves organizational performance (Daily \& Bishop, 2003; Lawler, 1994).

- Inspires change and enhances employee commitment to the achievement of organizational goals and success (Sahoo \& Das, 2011).

- Enables employees to forecast and foresee organizational changes, take ownership of solving problems or responding to marketplace opportunities and being proactive in making significant organizational decisions (Evans \& Lindsay, 2005).

- Motivates employees to exert optimum effort and be willing to take calculated risks (Gitlow et al., 2005).

- Leads to self-motivation, boosts confidence and employee morale.

- Enables self-managed work teams to effectively manage problems relating to productivity and quality (Elmuti \& Kathawala, 1997).

Skilful coaching is imperative in order to improve employee skills, performance and their ability to manage customer complaints and corrects problem behaviours. In addition, a supportive leadership style assists employees in improving processes in functional areas and quality, meeting customer needs and expectations and in self development. The aforementioned recommendations relating to participative management, when effectively implemented, have the potential to enhance total quality management. Studies of successful organizations reflect the importance of attaining productivity by effectively managing people, including their commitment and involvement in organizations, and their combined efforts. This collective effectiveness can only be inspired and sustained through the operating environment's ethics and culture of support championed by managerial leaders who have the ability to skilfully integrate the talents, capabilities and commitment of employees to ensure an organization spiralling to total quality management through competency and creativity. This, however, can only happen if quality is viewed as a foundational tool for their organization's strategic planning.

\section{References}

Alharbi, M. \& Yusoff, R. Z. (2012). Leadership Style, and their relationship with quality management practices in public hospitals in Saudi Arabia. International Journal of Economics \& Management Sciences, 1(10), 59-67.

Brown, P. (1999). Client-based management qualifications: A case of win-win? Journal of Management Development, 18(4), 350-361.

Crabb, S. (2011). The use of coaching principles to foster employee engagement. The Coaching Psychologist, 7(1), 27-34.

Daily, B. F. \& Bishop, J. W. (2003). TQM Workforce Factors and Employee Involvement: The Pivotal Role Of Teamwork. Journal of Managerial Issues, 15(4), 393-412.

Dale, B. G., van der Wiele, T. \& van Iwaarden, J. (2007). Managing Quality (5 ${ }^{\text {th }}$ ed), USA: Blackwell Publishing.

Davies, E. (2001). The quality gurus. Engineering Management Journal, 10, 223-229.

Elmuti, D. \& Kathawala, Y. (1997). Self-Managing Teams, Quality of Work Life and Productivity: A Field Study. American Journal of Business, 12(1), 19-26.

Evans, J.R. (2005). Total Quality: Management, Organization, and Strategy (4th ed), Canada: Thomson South-Western.

Evans, J. R. \& Lindsay, W. M. (2005). The Management and Control of Quality (6 $6^{\text {th }}$ ed), Singapore: Thomson South-Western.

French, R., Rayner, C., Rees, G. \& Rumbles, S. (2008). Organizational Behaviour, England: John Wiley \& Sons. 
Gitlow, H. S., Oppenheim, A. J., Oppenheim, R. \& Levine, D. M. (2005). Quality Management (3 ${ }^{\text {rd }}$ ed), Boston: McGraw Hill International Edition.

Ignite, I. (2007). A Situational Approach to Managing People. Ken Blanchard Companies: Newsletter. Retrieved from the World Wide Web on 11 July 2013: http://tr.51job.com/ kbc/April07_2.pdf

Jha, U. C. \& Kumar, S. (2012). Effect of TQM on employee satisfaction. Journal of Radix International Educational and Research Consortium, 1(8), 1-15.

Joiner, T. (2006). Total quality management and performance. The role of organization support and coworker support. School of Business, La Trobe University, 2(6), 617-627.

Korukonda, A. R., Watson, J. G. \& Rajkumar, T. M. (1999). Beyond Teams and Empowerment: A Counterpoint to two Common Precepts in TQM. Sam Advanced Management Journal, 3, 29-36.

Kreitner, R. (2007). Management (10 $10^{\text {th }}$ ed), Boston: Houghton Mifflin Company.

Lawler, E. E. (1994). Total Quality Management and employee involvement: Are they compatible? Academy of Management Executive, 8(1), 68-76.

Leonard-Cross, E. K. (2010). Developmental coaching: Business benefit - fact or fad? An evaluative study to explore the impact of coaching in the workplace. International Coaching Psychology Review, 5(1), 36-47.

Miller, R. L. \& Cangemi, J. P. (1993). Why Total Quality Management fails perspective of top management. Journal of Management Development, 12(7), 40-50.

Minjoon, J., Shaohan, C. \& Hojung, S. (2006). TQM practice in Maquiladora: Antecedents of employee satisfaction and loyalty. Journal of Operations Management, 13, 791-812.

Nadeem, J. (2012). Participative Management Style: A Tool to Enhance Quality Education. Journal of Humanities and Social Science, 4(2), 8-14.

Noe, R. A. (2008). Employee Training \& Development (4th ed), New York: McGraw Hill.

Noe, R. A., Hollenbeck, J. R., Gerhart, B. \& Wright, P. M. (2008). Human Resource Management: Gaining a Competitive Advantage. Boston: McGraw-Hill Irwin.

Oakland, S. \& Oakland, J. S. (2001). Current people management activities in world-class organizations. Total Quality Management, 12(6), 773-788.

Quang, T. \& Vuong, N. T. (2002). Management styles and organizational effectiveness in Vietnam. Research and Practice in Human Resource Management, 10(2), 36-55.

Quinn, R. E., Faerman, S. R., Thompson, M. P. \& McGrath, M. R. (2003). Becoming a Master Manager: A Competency Framework ( $3^{\text {rd }}$ ed), New York: John Wiley \& Sons.

Sahoo, C. K. \& Das, S. (2011). Employee Empowerment: A Strategy towards Workplace Commitment. European Journal of Business and Management, 3(11), 46-54.

Scully, J. P. (1993). A point of view: Actions speak louder than buzzwords. National Productivity Review, 12(4), 453-456.

Sekaran, U. (2003). Research Methods for Business: A Skill Building Approach (4th ed), United States of America: John Wiley \& Sons, Inc.

Taie, E. S. (2011). Coaching as an Approach to Enhance Performance. The Journal for Quality \& Performance, 3, 34-38.

Thamizhmanii, S. \& Hasan, S. (2010). A review on an employee empowerment in TQM practice. Journal of Achievements in Materials and Manufacturing Engineering, 39(2), 204-210.

Turney, P. B. B. (1993). Beyond TQM with Workforce Activity Based Management. Management Accounting, 1, 28-31.

Tushman, M. L. \& Anderson, P. (2004). Managing Strategic Innovation and Change (2 ${ }^{\text {nd }}$ ed), New York: Oxford University Press.

Ugboro, I. O. \& Obeng, K. (2000). Top management leadership, employee empowerment, job satisfaction, and customer satisfaction in TQM organizations: An empirical study. Journal of Quality Management, 5, 247-272.

Vinton, D. (1987). Delegation for employee development. Training and Development Journal, 41(1), 6567.

Vora, M. K. (2004). Creating employee value in a global economy through participation, motivation and development. Total Quality Management, 15(5-6), 793-806.

Whetton, D. A. \& Cameron, K. S. (2005). Developing Management Skills (6 th $^{\text {th }}$ ed), Canada: Pearson Education.

Wicks, A. C. (2001). The value dynamics of total quality management: Ethics and the foundations of TQM. Business Ethics Quarterly, 11(3), 501-526.

Zakuan, N, Muniandy, S., Saman, M. Z. M., Ariff, M. S. M., Sulaiman, S. \& Jalil, R. A. (2012). Critical Success Factors of Total Quality Management Implementation in Higher Education Institution: A Review. International Journal of Academic Research in Business and Social Sciences, 2(12), 19-32. 